\title{
Gümüşhane İklim Şartlarında Farklı Malzemeler İçin Yalıtım Kalınlıklarının TS 825 Kapsamında Değerlendirilmesi
}

\author{
Evaluation of Insulation Thicknesses For Different Materials Under Climatic Conditions of \\ Gümüşane Within the Scope TS 825
}

\author{
Faruk YEȘiLDAL ${ }^{1, a}$, Kadir GELİ̧ $^{* 2, b}$ \\ ${ }^{1}$ Atatürk Üniversitesi, Mühendislik Fakültesi, Makine Mühendisliği Bölümü, 25240, Erzurum \\ ${ }^{2}$ Bolu Abant İzzet Baysal Üniversitesi, Mühendislik Fakültesi, Makine Mühendisliği Bölümü, 14030, Bolu
}

\author{
• Geliş tarihi / Received: 10.04.2020 • Düzeltilerek geliş tarihi / Received in revised form: 17.06 .2020 • Kabul tarihi / Accepted: 23.06 .2020
}

\begin{abstract}
$\ddot{O} \mathbf{z}$
Bu çalışmada Gümüşhane iklim şartları ve meteorolojik değerleri göz önünde bulundurularak farklı yalıtım malzemeleri (XPS, EPS ve Taş yünü) için yalıtım kalınlığının (4-5-6 ve $8 \mathrm{~cm}$ ) değişimi ile toplam 1sı transfer katsayısının değişimi incelenmiştir. Değiş̧tirilen bu parametreler ile yıllık ısıtma enerjisi ihtiyacı yalıtımsız ve kısmi yalıtımlı duruma (taban ve tavan yalıtımlı) göre hesaplanmış ve karşılaştırmalı olarak değerlendirilmiştir. Hesaplamalar 1sı, su, ses ve yangın yalıtımcıları derneğinin (İzoder) TS 825 standartları kapsamında oluşturdukları "İzoder TS 825 Hesap Programı" ile yapılmıştır. Mimarilerde kullanılan duvar elemanlarına göre uygulanması gereken yalıtım kalınlığının değişiklik gösterebileceğini belirterek, örnek mimarinin duvar kesit özellikleri dikkate alındığında Gümüşhane ili için uygulanması gereken minimum yalıtım kalınlığının $4 \mathrm{~cm}$ olduğu hesaplanmıştır. Yapılan hesaplamalar sonucunda 1S1 yalıtım malzemesinin değiş̧imi ile yıllık enerji ihtiyacının değiştiği görülmüştür. Tamamen yalıtımsız duruma kıyasla çatının yalıtılmasının \% 27.6 enerji tasarrufu, toprağa temas eden taban ve duvarların yalıtılmasının ise \%16.9 enerji tasarrufu sağladığı hesaplanmıştır. Havayla temas eden düşey duvarda ise kullanılan malzemeye göre bu değer \%10.5$\% 17$ arasında değişmektedir.
\end{abstract}

Anahtar kelimeler: Enerji Tasarrufu, Isı Yalıtımı, TS 825

\begin{abstract}
In this study, considering the climatic and meteorological conditions of Gümüshane, the change of the insulation thickness (4-5-6 and $8 \mathrm{~cm}$ ) and the total heat transfer coefficient for different insulation materials (XPS, EPS and Rock wool) are investigated. With these changing parameters, the annual energy need for heating is calculated based on the uninsulated and partially insulated condition (floor and ceiling insulated) and evaluated comparatively. Calculations are made with "TS 825 Calculation Program" created by the heat, water, sound and fire insulators association (Izoder) within the scope of TS 825 standards. Insulation thickness that should be applied in accordance with the wall elements which used in architectures can vary, thus the minimum insulation thickness to be applied for Gümüşane province is calculated as $4 \mathrm{~cm}$ considering the wall cross-sectional properties of the sample architecture. As a result of the calculations, it has been observed that the annual energy need changes with the insulation material. It has been calculated that the insulation of the roof provides $27.6 \%$ energy saving compared to the completely uninsulated condition, and insulation of the floor and walls contacting the soil provides $16.9 \%$ energy saving. On the vertical wall contacting with air, this value varies between 10.5\%-17\% depending on the insulation material
\end{abstract}

Keywords: Energy Saving, Thermal Insulation, TS 825

\footnotetext{
*b Kadir GELİŞ, kadirgelis@ibu.edu.tr, Tel: (0374) 25410 00, orcid.org/0000-0001-8612-2233

${ }^{a}$ orcid.org/0000-0002-7307-3556
} 


\section{Giriş}

İnsan nüfusunun ve sanayileşmenin hızlı bir şekilde artışı ile birlikte Türkiye'de enerji tüketimi her geçen yıl artmaktadır. Bununla birlikte sera gazı etkilerinin yanı sıra, ülkemiz için dış ticaret açığı da oluşturan fosil yakıtların birincil enerjideki payı da \% 80'leri geçmiştir. Türkiye'de enerjinin $\% 35$ 'i konutlarda tüketilmektedir. $\mathrm{Bu}$ enerjinin ise $\% 65$ ' $\mathrm{i}$ de 1sitma, soğutma ve havalandirma amaciyla harcanmaktadır (Yaman ve Şengül, 2015). Bu sebeple enerji tasarrufu, tüketilen enerjinin çoğunu ithal eden ülkemiz için hayati öneme sahiptir. Enerjide dışa bağımlı olan ülkemiz için enerji tüketimini azaltacak 1sı yalıtım önlemlerinin alınması zorunludur. Bu da bizi enerji tasarruf potansiyeli yüksek olan konutlara yönlendirmektedir. Konutlarda enerji tasarrufu açısından en etkili yöntemlerden biri olan yalıtım; hem tüketilen enerjinin çevresel etkileri, hem de enerjinin yüksek maliyeti açısından özellikle ele alınması gereken bir konudur. Is1 yalıtımı kısa vadeli (enerji tasarrufu, ek yatırım maliyeti), uzun vadeli (yaşam döngüsü maliyet tasarrufu) ve bütünleşik etkileriyle (geri ödeme süresi, karbon ayak izi) birlikte değerlendirilmelidir.

Literatürde binalarda kullanılan 1 s1 yalıtım malzemeleri, duvar tipleri, optimum yalitım kalınlıkları, geri ödeme süresi analizi, TS-825 standardına uygunluk, çevresel etkiler, yoğuşma, yalıtımın uygulama şekli ve yurtdışındaki uygulamalar konularında yapılan çalışmalar özetlenmiştir.

Araştırmac1 (Bolattürk, 2006) Türkiye'nin dört farklı iklim bölgesinden 16 şehir için optimum yalıtım kalınlıkları, enerji tasarrufu ve geri ödeme süreleri hesaplamış ve yaşam döngüsü maliyet analizini esas alarak optimum yalıtım kalınlılarını belirlenmiş̧ir. Bunun için beş farklı yakıt (kömür, doğal gaz, fuel oil, LPG ve elektrik) ve yalıtım malzemesi olarak da polistiren kullanmıştır. Sonuç olarak incelenen bölge ve yakıt tipine bağlı olarak \%22 - \%79 arasinda enerji tasarrufu, 1.3 ile 4.5 y1l arasında geri ödeme süresi ve $2-17 \mathrm{~cm}$ gibi geniş bir aralıkta yalıtım kalınlığı elde etmiştir. Çomaklı ve arkadaşları (Çomaklı and Yüksel, 2003) çalışmalarında 4. bölgede bulunan ve ülkemizin en soğuk bölgesinden Erzurum, Kars ve Ardahan illeri için yaptıkları yaşam döngüsü maliyet analizi ile optimum yalıtım kalınlıklarını araştırarak Erzurum gibi soğuk iklimlere sahip şehirlerde tasarrufun 10 y1l boyunca 12.13718 \$ / $\mathrm{m}^{2}$ kadar olabileceğini belirttiler. Araştırmacı (Özel, 2019) 4. bölgede ve ülkemizin en soğuk bölgesinde yer alan Kars ili için yaptığ 1 bu çalışmada bina dış duvarları için dört farklı yapı malzemesi (taş, tuğla, beton ve gaz beton) ve yalitım malzemesi olarak da EPS kullanarak 1sıtma yüklerini yalıtımlı ve yalıtımsız durumlar için karşılaştırmıştır. Artan yalıtım kalınlıklarına göre 1sı kayıplarını çok katmanlı duvarlar için bir boyutlu is1 iletim denklemini sonlu farklar yöntemi ile analiz etmiştir. Araştırmacılar (Şahin ve Çarkac1, 2019) 4. bölgede olan Gümüşhane ili için örnek bir kamu lojman binasında TS 825'e göre diştan mantolama yaptılar. Binayı yalıtım yapılmadan önce ve yalıtımdan sonra aldıkları termal kamera görüntüleri üzerinden incelediler. Sonuç olarak yaptıkları karşılaştırmada mevcut yalıtımlı durum için yalıtımsız duruma göre $\% 39.5$ ' lik, TS 825 'e göre yapılmas1 gereken yalıtım için yalıtımsız duruma göre \%50.9' luk bir tasarruf sağlanacağını belirttiler. Geri ödeme süreleri değerlendirildiğinde TS 825 e göre yapılan yalıtım için amortisman süresinin biraz arttığı, ancak yıllık yakıt tüketiminin azaldığını gördüler. Bu çalışmada (Dikmen, 2019) 1995 Dinar Depremi'nden sonra inşa edilmiş olan afet konutu projesinin TS 825 Binalarda Is1 Yalitım Kuralları'na uygunluğunu İzoder TS 825 hesap programını kullanarak inceledi. Öncelikle projenin mevcut durumunun TS 825 standardina uygunluğunu incelemiş, daha sonra projeyi 3 farklı aşamada standarda uygun hale getirmiştir. Sonuç olarak çatıda kullanılmış olan cam yününü $5 \mathrm{~cm}$ 'den $12 \mathrm{~cm}$ 'ye çıkarmış; duvarlarda $8 \mathrm{~cm}$ EPS ve toprağa oturan döşemede $7 \mathrm{~cm}$ XPS kullanmıştır. Araştırmacı (Fertelli, 2013) Türkiye'de yaygın olarak kullanılan farklı duvar tiplerinin (taş, tuğla, beton ve bims) optimum yalıtım kalınlıkları, enerji tasarrufu ve geri ödeme süreleri üzerindeki etkisini altı farklı yakıt türü (LPG, elektrik, akaryakıt, kömür, doğal gaz ve jeotermal enerji) için değerlendirmiştir. Farklı iklim bölgelerinden dört şehir (Aydın, Trabzon, Malatya ve Sivas) seçerek, iki farklı yalıtım malzemesiyle (XPS ve Taş yünü) analiz yaptılar. Sonuçları, yalıtım kalınlıklarının $0-0.179 \mathrm{~m}$ aralığında enerji tasarrufu için çeşitli yakıt ve duvar tiplerine bağlı olarak $0-235.053 \$ / \mathrm{m}^{2}$ ve geri ödeme süresini ise $0-11.53$ y1l olarak elde etmişlerdir. Bir başka çalışmada TS 825 'e uygun olarak çeşitli duvar tiplerinin termal etkinlikleri karşılaştırmalı olarak incelenmiş̧ir. Araştırmacılar yapıların enerji etkin özelliklere sahip olmasını amaçlamışlardır. Örnek olarak 3. derece gün bölgesinde betonarme iskelet bir yapıyı ele alarak farkl1 yap1 bileşenleriyle mevcut 1s1 iletkenlik değerleri için TS 825 kapsamında uygun kalınlıkları belirlemişlerdir. Ayrıca yoğuşma açısından da inceleme yaparak yoğuşma 
bölgelerini analiz etmişlerdir (Yüksek ve Sivacilar, 2017).

Bitlis ili için yürütülen başka bir yalıtım uygulamasında yoğuşma riski de dikkate alınarak aylara göre gerekli minimum yalıtım kalınlıkları hesaplanmıştır. Yapı elemanındaki 1sı ve kütle transferi hesaplamalarını, farklı iç ortam sıcaklıkları ve bağıl nem koşulları için yaparak DG4 bölgesinde bulunan Bitlis ili için şubat ayında yapılarda görülen yoğuşma riskinin diğer aylara göre daha yüksek olduğunu belirtmiştir. Ayrıca şubat ayı için gerekli minimum yalıtım kalınlığını yaklaşık $0.104 \mathrm{~m}$ olarak önermiştir. (Bademlioğlu vd., 2018). Araştırmacı bu çalışmada EPS, MW (mineral yün) ve GC (gaz beton) yalıtım malzemelerini kullanılarak TS 825 standardına uygun olarak yoğuşma analizi yapmıştır. Farklı iç ortam sıcaklıkları için duvar içerisindeki basınç değişimlerini göstermiştir. Düşük sıcaklıklarda basınç değerlerinin yüksek ve yüksek iç ortam sıcaklıklarında ise basınç değerlerinin düşük olduğunu görmüştür. İç ortam sıcaklığının artmasıyla yapı bileşenleri arasında yoğuşmaların olabileceğini belirtmiştir (Uzun, 2020). Türkiye'nin 81 il merkezi için optimum yalıtım kalınlıklarının belirlendiği bu çalışmada hesaplamalar, 4 farklı yakıt (doğal gaz, kömür, fuel oil ve LPG) ve 5 farkl yalitım malzemesi (XPS, EPS, cam yünü, taş yünü ve poliüretan) için yapılmıştır. Çalışmada isıtılan fakat soğutulmayan, soğutulan ancak 1sitılmayan ve hem isitılan hem de soğutulan durumlar için; her bir duruma göre gerekli optimum yalıtım kalınlıkları belirlenmiştir. Yakıtlara ve yalıtım malzemelerine göre optimum yalıtım kalınlıklarını, toplam net tasarruf miktarı, geri ödeme süresi değişimi ve derece / gün değerlerine göre seçilen 5 farklı il merkezi için (İzmir, İstanbul, Ankara, Sivas ve Erzurum) hesaplamıştır. Sonuçta doğal gaz için hem olumsuz çevresel etkilerinin, hem de optimum yalıtım kalınlığının diğer yakıtlara göre daha düşük olduğunu ve ilk yatırım maliyetinin de daha düşük olacağını belirtmiştir (Kürekçi, 2016). Altun ve arkadaşları yürüttükleri çalışmada binaların erken tasarım aşamasında planlanan ilave kabuk yalıtımı yatırımlarının, Türkiye'deki 81 il için y1llık ve yaşam döngüsü perspektiflerinden 1sitma ihtiyac1, maliyet ve karbon ayak izi açısından etkinliğini araştırmışlardır. Binanın yıllık 1sıtma alanı ihtiyacını TS 825 standard1 metodolojisine göre hesaplamışlardır. Isı yalıtım analizi için Türkiye'de 81 ilde bir vaka çalışması binası için yalıtılmamış bina, TS 8252008 versiyonunun asgari şartlarına göre yalıtılmış bina ve TS 825-
2013 versiyonunun minimum gereksinimlerine göre yalıtımlı üç farklı yalıtım tasarımı alternatifi oluşturarak yalıtımsız bir binanın TS 825'e göre yalıtım etkinliğini kısa dönem (yıllık 1sıtma enerji ihtiyacında sağlanan tasarruf, ek yalıtım maliyeti ve ek sera gazı salımı) ve yaşam döngüsü (yaşam döngüsü maliyeti ve sera gazı salımı) olmak üzere iki farklı süreçte incelemişlerdir. Analizler, standarda dayalı yalıtımların, yalıtımsız binaya göre yıllık 1sıtma enerjisi için $\% 75^{\prime}$ e, yaşam döngüsü maliyetinde $\% 70$ 'e ve yaşam döngüsü sera gazı emisyonları için \%73'e varan iyileştirmeler sağladığını göstermiş̧tir. Ayrıca, geri ödeme sürelerini maliyet için 7 yılın altında ve sera gazı emisyonları için 2 yılın altında elde etmişlerdir (Altun vd., 2020). Altun ve arkadaşları başka bir uygulamada ise, bir binanın enerji ihtiyacını bina kabuk elemanlarını geometrik verilerine ve termal özelliklerine göre hesaplamışlardır. Çalışmalarında model tabanlı TS 825 analizi için bir uygulama geliştirmişlerdir. Çalışmayı denetim, analiz ve kontrol olarak üç modda tanımlayarak TS 825 standardının hesaplama gereksinimlerine göre bir örnek binada test etmiş ve sonucu, doğruluk analizi için manuel hesaplamalarla karşılaştırmışlardır. Sonuçta TS 825 analizinin tutarlı olduğunu doğrulamışlardır (Altun ve Akçamete Güngör, 2019). Araştırmacılar Erzincan ilinde yürüttükleri bu deneysel çalışmada günümüzde 1s1 yalıtım malzemesi olarak en çok kullanılan EPS ile genleştirilmiş perlitin isı yalıtım performanslarının 1sıl dirençler açısından karşılaştırılmasını yapmışlardır. Sonuç olarak $6 \mathrm{~cm}$ 'lik EPS ile 8 cm'lik genleştirilmiş perlitin 1s1 yalıtım kapasitelerinin denk olduğunu elde etmişlerdir (Kotan vd., 2018). DG3 bölgesinde bulunan Malatya ilinde yürütülen bu çalışmada, iki farklı yalıtımlı duvar (dıştan yalıtımlı ve sandviç), iki farkl1 yalıtım malzemesi (XPS ve EPS) ve iki farklı yakıt türü (doğalgaz ve kömür) kullanarak yalıtım malzemesinin optimum kalınlıklarını, enerji tasarrufu ve geri ödeme sürelerini sadece 1sitma, sadece soğutma ve hem 1sitma hem de soğutma için ayrı ayrı hesaplamışlardır (Uçar ve Dumrul, 2019). İmal ve çalışma arkadaşı Kahramanmaraş ilindeki bazı örnek binalara uygulanan 1sı yalıtım malzemeleri, özellikleri, uygulandığ1 yerler ve yalıtımın yıllık yakıt giderlerine etkisini maliyet açısından araştırmışlardır. Üç farklı 1sı yalıtım malzemesinin (XPS, EPS ve Poliüretan) incelendiği çalışmada İzoder TS825 standartlarından yararlanarak 1S1 yalıtımlı ve yalıtımsız durumlar için yaptıkları karşılaştırmada yalıtımlı durumda enerji tasarrufunun yaklaşık \%80'e kadar vardığını belirtmişlerdir (İmal ve Karayiğit, 2014). 
Dünyanın farklı bölgelerinde yalıtım kalınlı̆̆ geri ödeme süresi ve kullanılan yapı malzemeleri açısından birçok çalışma yapılmıştır. Örneğin bu çalışmada İran'ın tüm iklim bölgelerinde dış duvarın ideal yalıtım kalınlığını, enerji tasarrufunu ve yatırım geri ödeme süresini belirlemeyi amaçlamışlardır. Klasik bir gri tuğla duvar ve üç modern duvar (İçi boş kil blok, LECA blok ve AAC blok) için çalışmayı yürüttüler. Tüm iklim bölgelerinden sekiz şehir seçerek, iletim yükünü belirlemek için sayısal bir çözümle birlikte yaşam döngüsü maliyet analizi yöntemini kullanarak optimizasyon yapmışlardır. Sonuçların İran'da kullanılan modern duvarlardan biri olan AAC blok duvarında 1s1 yalıtımı uygulamasının bazı şehirlerde ekonomik olmadığını belirtmişlerdir. İran'daki maksimum yalıtım kalınlığının 4 cm'den fazla olmadığını ve bunun da diğer ülkeler için bildirilen değerlerden çok daha düşük olduğu sonucuna varmışlardır (Rosti vd., 2020). Cezayir için yapılan çalışmada araştırmacılar enerji performansinı incelemek ve klasik bir ev ile karşılaştırmak için bir prototip yapının deneysel ve sayısal çalışmasını yürütmüşlerdir. Yı1lık soğutma ve 1sıtma iletim yüklerini, üç farklı yapı malzemesi için (delikli tuğla, yığma taş, beton) EPS'nin yalıtım kalınlığının artışına göre hesaplamışlardır. Ayrıca cam tipinin ve duvardaki cam yüzdesinin etkisini, yalıtımın optimum kalınlığını belirlemek için incelemişlerdir (Derradji vd., 2017). İtalya'da yapilan bir çalışmada araştırmacılar 1sı yalıtımı ile ilgili somutlaştırılmış enerji etkisini değerlendirmiş ve verimlilik önlemleri olarak enerji ve karbon geri ödemesini belirlemişlerdir. On İtalyan şehrini analiz etmiş ve sonuçların iklim bölgesine bağımlılığını göstermişlerdir. Daha soğuk iklim bölgelerinde olan Kuzey İtalya şehirlerinde, enerji ve karbon geri ödeme sürelerini 3 y1l, güneydeki Palermo şehri için 84 yıl olarak elde etmişlerdir. Optimum kalınlığı, binanın tipi, yalıtım malzemeleri ve enerji geri ödemesi sürelerini dikkate alarak Milano şehri için tahmin etmişlerdir (Abd Alla vd., 2020). Başka bir çalışmada araştırmacılar, Polonya'da bulunan beş iklim bölgesinde iki farklı bina için dış duvarların 1s1 yalıtımını içeren bir yatırım için bir yöntem ve ekolojik maliyet etkinliği analizi önermişlerdir. Araştırmacılar çalışmalarını yaşam döngüsü değerlendirme (LCA) tekniğine dayandırmışlardır. Analizde, 1S1 kaynakları, 1S1 yalıtımı ve inşaat malzemeleri ile analiz edilen binalarm kullanılabilir alanları gibi farklı bileşenlerini dikkate almışlardır. Ekolojik maliyet etkinliğinin en elverişli değerlerini, inceledikleri ekolojik 1s1 yalıtım malzemelerinden eko-fiber için Polonya'daki en soğuk iklim bölgesinde ekolojik geri ödeme süresini 0-6 yaş aralığında elde etmişlerdir (Dylewski ve Adamczyk, 2016).

Yapılan literatür taraması 1şı̆̆ında konutlarda 1S1 yalıtım tedbirlerinin enerji tasarrufu açısından hayati öneme sahip olduğu, bölgesel olarak farklı 1S1 yalıtım malzemelerinin ve kalınlıklarının uygulanabileceği anlaşılmıştır. Ülke olarak enerji tüketiminin büyük yüzdesini oluşturan konutlardaki ısınma ihtiyacının verimli bir hale getirilmesi önemli bir konudur.

T.C. Çevre ve Şehircilik Bakanlığı'nın açıkladığı verilere göre ülkemizde elektrik enerjisi tüketimi 2018 y1lında bir önceki y1la göre \%2.2 artmış ve 304.2 milyar kWh olarak hesaplanmıştır. Elektrik tüketiminin 2023 y1lına kadar yıllık ortalama $\% 4.8$ artışla 375.8 TWh değerine ulaşması beklenmektedir. Elektrik üretimimiz ise 2018 y1lı itibariyle, \%37.3 kömürden, \%29.8 doğal gazdan, \%19.8 hidrolik enerjiden, \%6.6 rüzgârdan, \%2.6 güneşten, $\% 2.5$ jeotermal enerjiden ve $\% 1.4$ diğer kaynaklardan sağlanmıştır (URL-1). Buna göre, arzının giderek artması, genellikle fosil veya dışa bağımlı kaynaklardan elektrik üretilmesi ve yenilenebilir enerji kaynaklarının kullanım oranının düşük olması gibi nedenlerden dolayı enerji tasarrufuna yönelik çalışmalar yapılması gerektiği açıktır. Ülkemizde sektörel bazda enerji tüketimi verilerine göre konutlar \%27'lik oranla büyük bir pay sahibidir. Enerji tüketim oranları (Şekil 1) ve bunun binalarda dağılımı (Şekil 2) görülmektedir. Bunun için binaların optimum şekilde yalıtılması gerekmektedir.

Konut sektörü, endüstri sektörü ile birlikte küresel enerji talebinin en fazla olduğu yerlerdir. Binalarda enerji tüketiminin \% 65'i de 1sitma amaçlı kullanılmaktadır (Şekil 2). Isı yalıtımının ciddi bir enerji tasarrufu sağlayacağı açıktır. Ulusal hedeflerimiz doğrultusunda yürürlükteki TS 825 standardında binaların yalıtımı konusunda hem farkındalık yaratmak hem de teşvik etmek oldukça önemlidir. Ülkemizde yalıtım yapılmayan birçok bina mevcuttur. Yapılacak uygun yalıtım uygulamalarıla tüketilen enerjinin \% 50' den daha fazlasının tasarrufu mümkündür. Ekonomik avantajının yanında 1S1 yalıtımı uygulamas1, 1s1 konfor etkileri, ekoloji ve çevre açısından uzun vadeli kazanımlarıyla birlikte ele alınmalıdır.

$\mathrm{Bu}$ çalışmada uygulamada yaygin olarak kullanılan 3 farklı yalıtım malzemesinin (XPSEPS ve taş yünü) farklı yalıtım kalınlıkları (4-5-6 ve $8 \mathrm{~cm}$ ) için toplam 1sı transfer katsayıları (U) ve y1ll1k 1sitma enerjilerinin DG4 bölgesindeki Gümüşhane ilindeki örnek bir bina için analiz edilmesi amaçlanmaktadır. Analizler İzoder TS 825 Hesap Programı kullanılarak yapılmıştır. 


\section{Enerji Tüketimi}

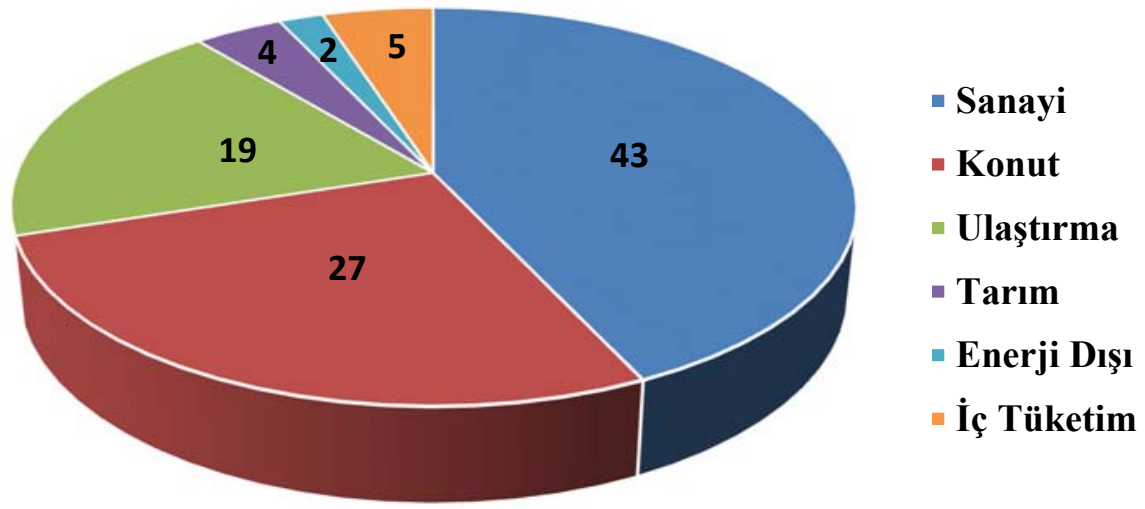

Şekil 1. Türkiye'de sektörel bazda enerji kullanımı (URL-2)

\section{Enerji dağılımı}

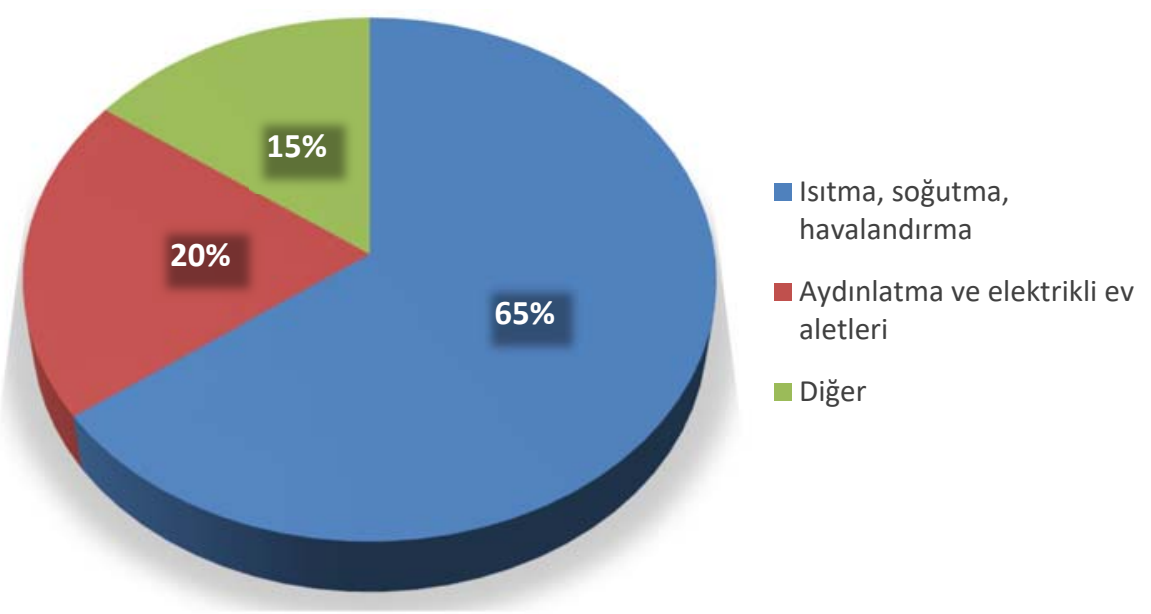

Şekil 2. Binalarda enerji tüketimi (URL-3)

\section{Materyal ve Metot}

\subsection{Materyal}

Çalışmada örnek alınan mimari Bodrum+Zemin +3 kattan oluşan 8 dairelik bir apartmandır. Örnek mimari binanın projesinde duvar kesiti içten dışa doğru alçı-gaz betonçimento harc1-yalıtım malzemesi-çimento harc1 sıralamasıyla sunulmuştur. Mimariyi oluşturan duvar kesiti Şekil 3'de ve duvar kesitinin oluşturan yapı elemanlarının kalınlıkları Tablo 1 'de verilmiştir. Duvar yapısında bütün elemanlar aynı özellik ve kalınlıklarda kalırken; sadece cephe kaplamasında kullanılan yalıtım malzemesi EPS, XPS ve taş yünü olarak seçilmiş ve kalınlığın (4-5-6-8 cm) toplam $1 \mathrm{~s} 1$ transfer katsayıs1 (U) ve y1llık 1sitma enerjisini nasıl değiştirdiği hesaplanmıştır.

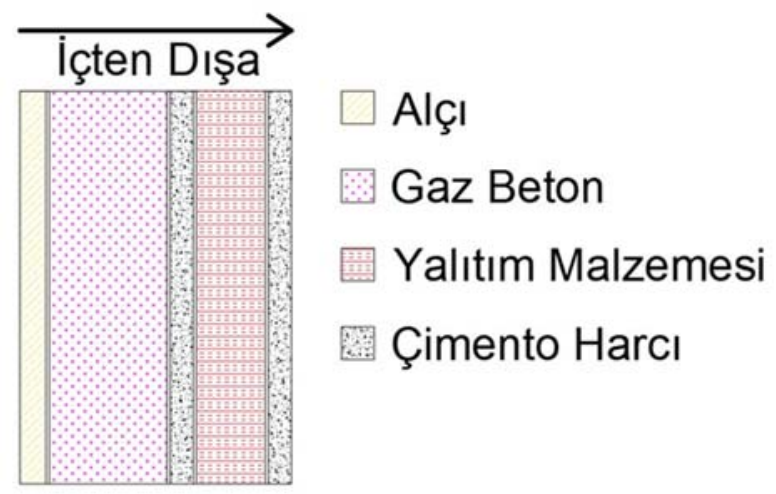

Şekil 3. İçten dişa doğru duvar kesitini oluşturan malzemeler 
Tablo 1. Duvar kesitini oluşturan malzemelerin kalınlıkları

\section{Malzeme Cinsi}

Kalınlık (cm)

Alçı 2

Gaz Beton

Yalıtım Malzemesi (XPS-EPS- 4-5-6-8

Taş Yünü)

Çimento Harc1 (Toplam)
İzoder TS 825 Hesap programı kullanılarak 1S1 yalıtım hesabı yapılan örnek mimarinin teknik resim görünüşleri Şekil 4, Şekil 5 ve Şekil 6'da sunulmuştur.
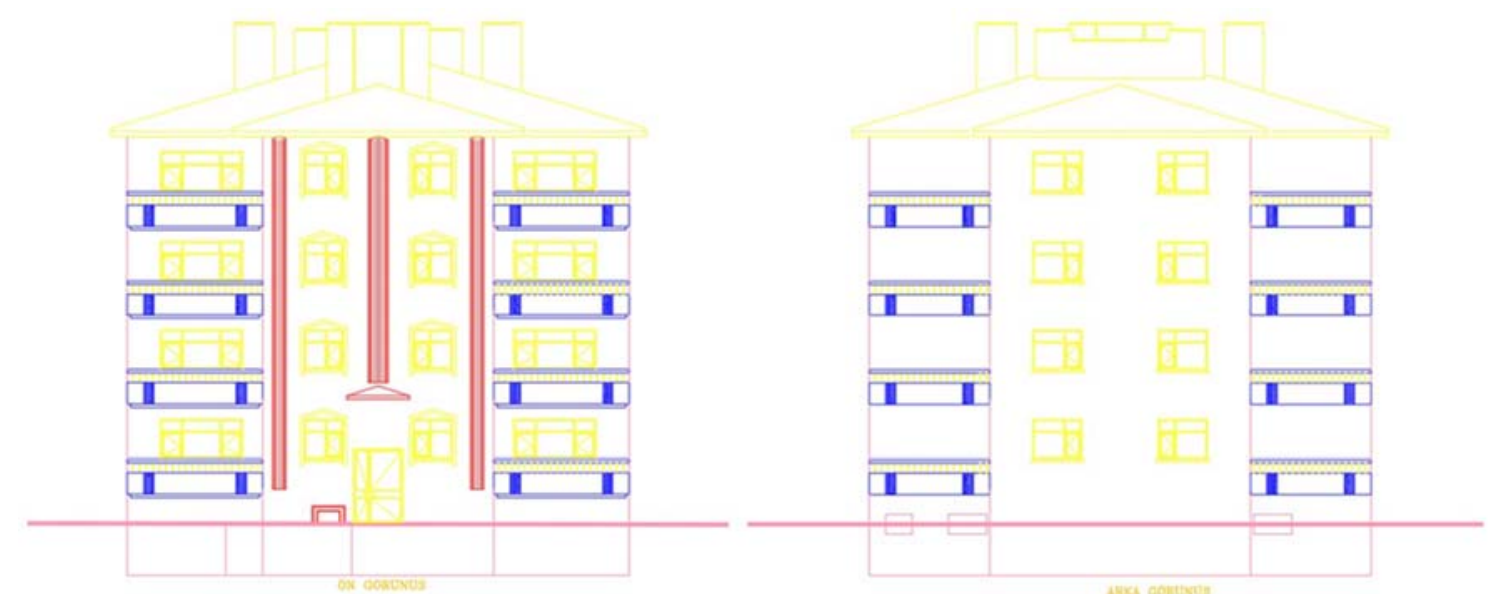

Şekil 4. Örnek binanın ön ve arka görünüşleri
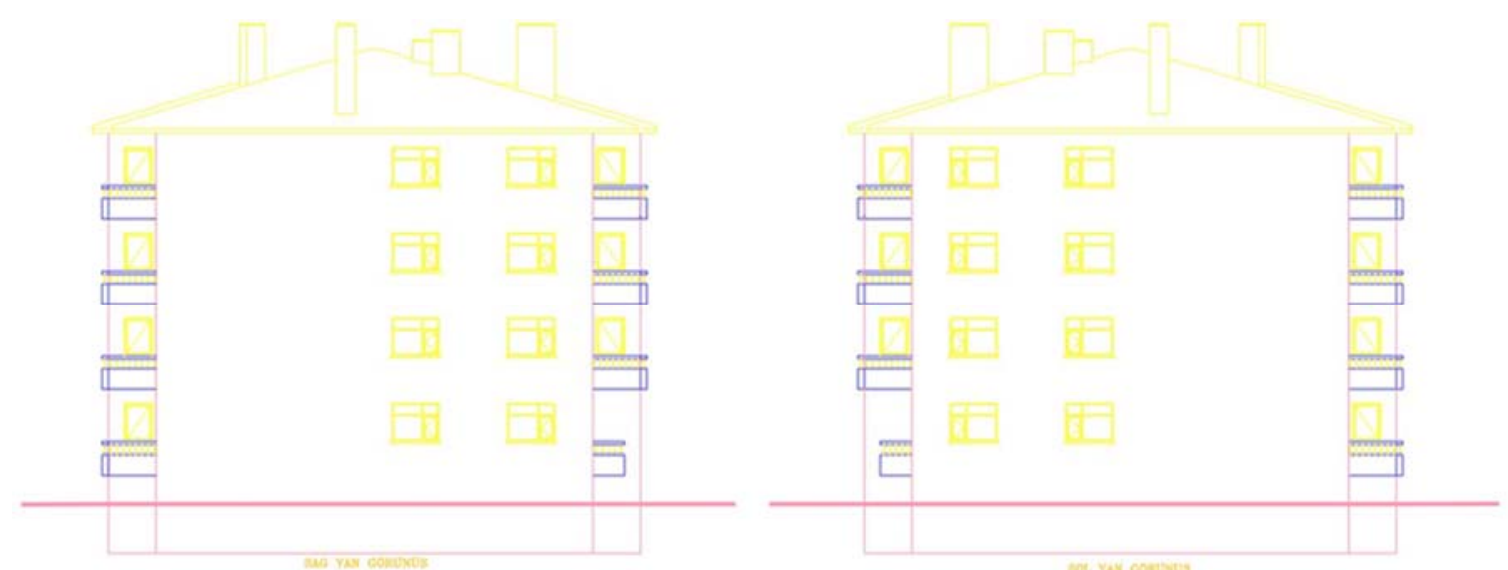

Şekil 5. Örnek mimarinin sağ ve sol yan görünüşleri

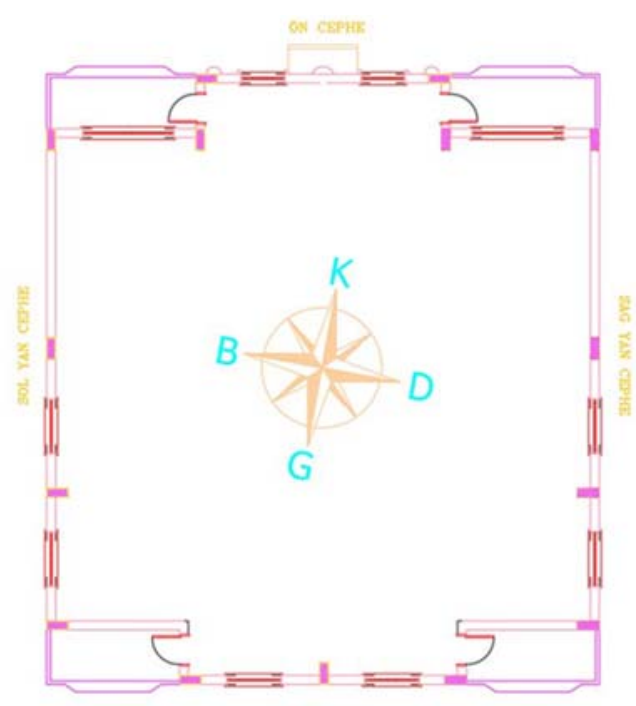

Şekil 6. Örnek mimarinin yönleri 
Örnek mimari proje üzerinden İzoder TS 825 hesap programının talep ettiği bilgiler doğrultusunda yapılan yüzey alanı hesapları Tablo 2'de sunulmuştur.

Örnek binanın kat yüksekliği $2.7 \mathrm{~m}$ ve toplam brüt hacmi $3382.7 \mathrm{~m}^{3}$ tür. Güneş Enerjisi Kazanc1 hesabı yapılırken yönlere bağlı toplam pencere alanları Tablo 3'te verilmiştir.

Çalışmada 8 daire olarak tasarlanmış örnek mimarinin duvar yap1 elemanlar1 sabit tutularak yalıtım malzemesinin cinsi (EPS, XPS, taş yünü) ve yalıtım malzemesi kalınlığı $(4-5-6-8 \mathrm{~cm})$ değiştirilmiştir. Piyasada kullanılan, XPS, EPS ve taş yününün görselleri Şekil 7'de verilmiştir. TS 825 standartlarında yer alan malzeme özelliklerine göre XPS yalıtım malzemesinin 1sıl iletkenlik değerleri $0.030-0.040 \mathrm{~W} / \mathrm{mK}$ aralı̆̆ında, EPS yalıtım malzemesinin 1sıl iletkenlik değerleri 0.035-0.040 W/mK aralığında ve taş yünü yalıtım malzemesinin 1s1l iletkenlik değerleri 0.035-0.050 $\mathrm{W} / \mathrm{mK}$ aralığında değişmektedir. Bu örnek mimari üzerine uygulanan yalıtım malzemelerinin 1 sıl iletkenlik seçimleri piyasada sıkça kullanılan katalog değerleri de göz önünde bulundurularak uygulamaya en yakın olan değerlerden seçilmiş ve teknik özellikleri Tablo 4'te verilmiş̧ir.

Tablo 2. Proje Hesabında kullanılan yüzeyler ve alanları

\begin{tabular}{ll}
\hline Yüzey Adı & Yüzey Alanı $\left(\mathrm{m}^{2}\right)$ \\
\hline Dış Havaya Açık Duvar & 636.5 \\
Toprağa Temas Eden Duvar & 69 \\
Kırma Çatı & 255.3 \\
Toprağa Temas Eden Taban & 255.3 \\
Dış Ortama Bakan Kapı ve Pencere & 105.1 \\
Dış Kapı-Metal (Isı Yalıtımlı) & 3.3 \\
\hline
\end{tabular}

Tablo 3. Güneș enerjisi kazancı hesabında kullanılan yön bazlı pencere alanları

\begin{tabular}{cc}
\hline Yön & Pencere Alan1 $\left(\mathrm{m}^{2}\right)$ \\
\hline Doğu & 27.6 \\
Batı & 27.6 \\
Kuzey & 14.4 \\
Güney & 35.5 \\
\hline
\end{tabular}

Tablo 4. Kullanılan yalıtım malzemelerinin özellikleri

\begin{tabular}{lll}
\hline Malzeme Ad1 & Birim Hacim Kütlesi $\left(\mathrm{kg} / \mathrm{m}^{3}\right)$ & Is1l İletkenlik $(\mathrm{W} / \mathrm{mK})$ \\
\hline XPS & 25 & 0.030 \\
EPS & 20 & 0.035 \\
Taş Yünü & 150 & 0.040 \\
\hline
\end{tabular}

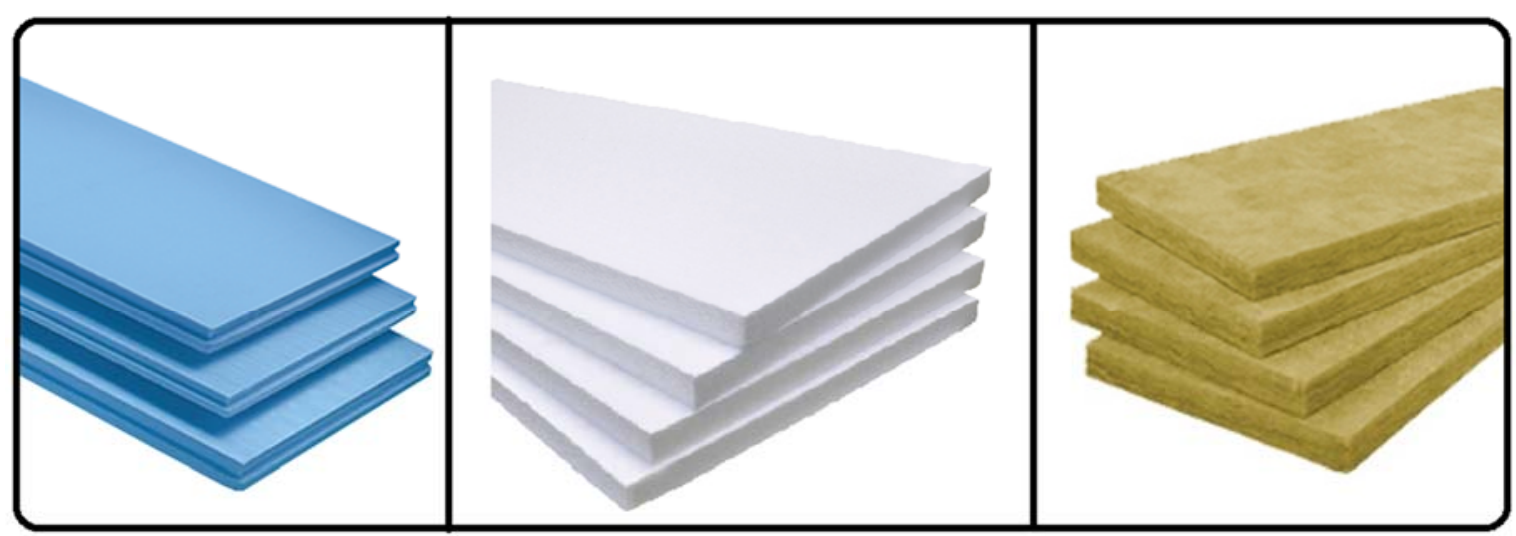

(a)

(b)

(c)

Şekil 7. Örnek mimaride kullanılan ısı yalıtım malzemeleri, (a) XPS, (b) EPS, (c) Taş yünü

Örnek mimari yapıda 4 farklı duvar tipi ile karşılaşılmaktadır. Bu farklı duvar tipleri için TS 825 farklı U değerleri öngörmektedir. Bu sebeple hesaplamaya dâhil edilen duvar tiplerinin daha anlaşılır olabilmesi için Şekil 8'deki görsel sunulmuştur. 


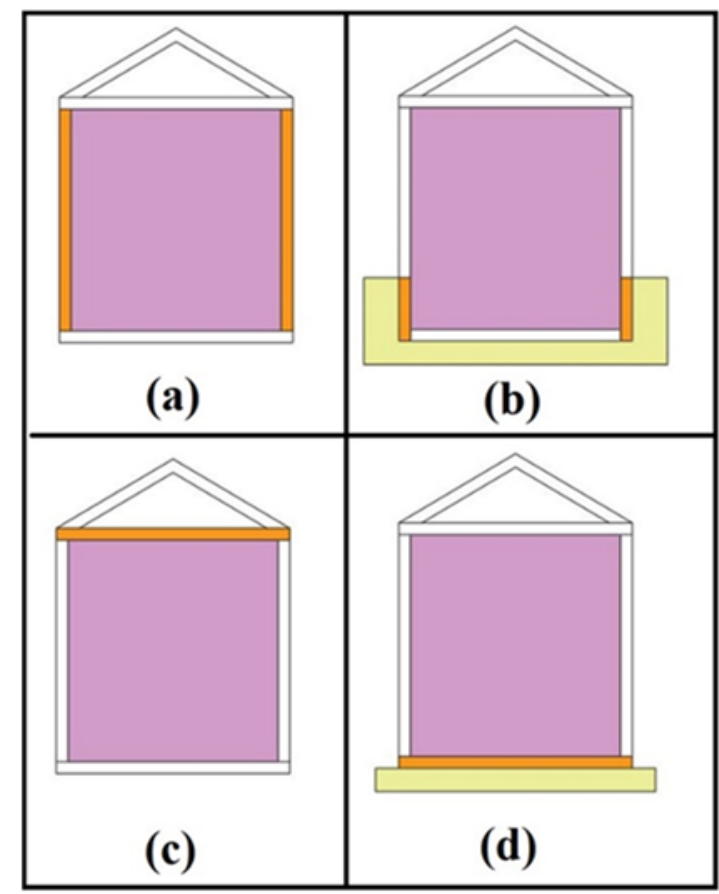

Şekil 8. Dış havaya açık duvar (a), Toprağa temas eden duvar (b), Kırma çatı (c), Toprağa temas eden taban (d)

TS 825 Binalarda 1s1 yalitım kuralları standartlarında Türkiye 4 farklı derece gün olarak değerlendirilmektedir. 1. Derece gün Türkiye'de en sicak iller iken 4. Derece gün illeri Türkiye'nin en soğuk illeridir. TS 825 standardında yer alan derece gün bölgelerine göre illerimiz Şekil 9'da sunulmuştur.

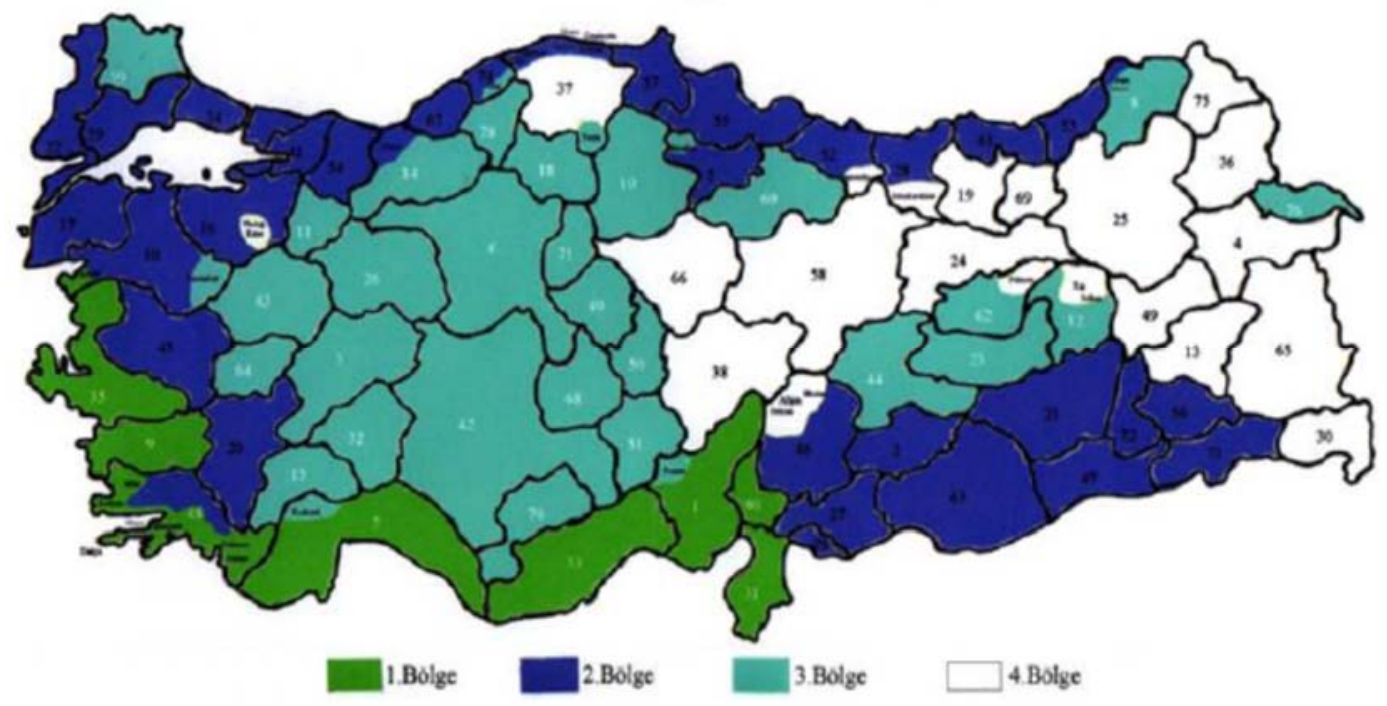

Şekil 9. Derece gün bölgelerine göre illerimiz (URL-4)

TS 825 standartlarına göre 1sıtması yapılan herhangi bir mahallin bina tipine göre iç ortam sıcaklığ1 sabitken, projelendirmenin yapıldığ 1 ilin hangi derece gün bölgesinde bulunduğuna göre dış ortam sıcaklıkları aylık olarak değişmektedir. Gümüşhane 4. Derece gün bölgesinde bulunan bir il olup ve Türkiye'nin en soğuk illerinden biridir. Dolayısıyla burada yapilacak olan yalitım hesab1 diğer gün derece bölgelerinde bulunan illerimize göre daha önemlidir. TS 825 Standardına göre farklı derece gün bölgeleri için yıllık 1sıtma enerjisi ihtiyac1 Tablo 5'te sunulmuştur. Tablo 5'te sunulan sinır değerlerinin üzerinde hesaplanan herhangi bir y1llik enerji ihtiyac1 durumunda yapılan yalıtımın yetersiz olduğu anlaşılır. 
Tablo 5. Farklı derece gün (DG) bölgeleri için yıllık 1sıtma enerjisi ihtiyacı sınır değerleri (URL-4)

\begin{tabular}{|c|c|c|c|c|c|}
\hline & $\mathrm{h}(\mathrm{m})$ & $\begin{array}{l}\mathrm{A} / \mathrm{V} \leq 0.2 \\
\mathrm{için}\end{array}$ & $\begin{array}{l}0.2<\mathrm{A} / \mathrm{V}< \\
1.05 \text { için }\end{array}$ & $\begin{array}{l}\mathrm{A} / \mathrm{V} \geq \\
1.05 \text { için }\end{array}$ & Birim \\
\hline \multirow[t]{2}{*}{ Q'1.DG } & $\mathrm{h} \leq 2.6 \mathrm{~m} \mathrm{~A} \mathrm{~A}_{\mathrm{N}}$ ile ilişkili & 19.2 & $44.1 \mathrm{~A} / \mathrm{V}+10.4$ & 56.7 & $\mathrm{kWh} / \mathrm{m}^{2}$ \\
\hline & 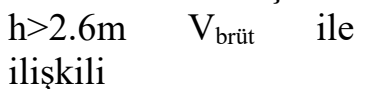 & 6.2 & $14.1 \mathrm{~A} / \mathrm{V}$ & 18.2 & $\mathrm{kWh} / \mathrm{m}^{3}$ \\
\hline \multirow[t]{2}{*}{ Q'2.DG } & $\mathrm{h} \leq 2.6 \mathrm{~m} \mathrm{~A}_{\mathrm{N}}$ ile ilişkili & 38.4 & $70 \mathrm{~A} / \mathrm{V}+24.4$ & 97.9 & $\mathrm{kWh} / \mathrm{m}^{2}$ \\
\hline & 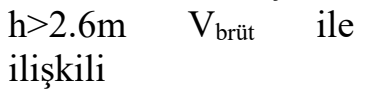 & 12.3 & $22.4 \mathrm{~A} / \mathrm{V}+7.8$ & 31.3 & $\mathrm{kWh} / \mathrm{m}^{3}$ \\
\hline \multirow[t]{2}{*}{ Q'3.DG } & $\mathrm{h} \leq 2.6 \mathrm{~m} \mathrm{~A}_{\mathrm{N}}$ ile ilişkili & 51.7 & $76.3 \mathrm{~A} / \mathrm{V}+36.4$ & 116.5 & $\mathrm{kWh} / \mathrm{m}^{2}$ \\
\hline & 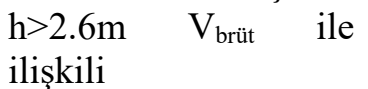 & 16.6 & $24.4 \mathrm{~A} / \mathrm{V}+11.7$ & 37.3 & $\mathrm{kWh} / \mathrm{m}^{3}$ \\
\hline \multirow[t]{2}{*}{ Q'4.DG } & $\mathrm{h} \leq 2.6 \mathrm{~m} \mathrm{~A}_{\mathrm{N}}$ ile ilişkili & 67.3 & $82.8 \mathrm{~A} / \mathrm{V}+50.7$ & 137.6 & $\mathrm{kWh} / \mathrm{m}^{2}$ \\
\hline & $\begin{array}{lll}\mathrm{h}>2.6 \mathrm{~m} & \mathrm{~V}_{\text {brüt }} \quad \text { ile } \\
\text { ilișkili } & & \end{array}$ & 21.6 & $26.5 \mathrm{~A} / \mathrm{V}+16.3$ & 44.1 & $\mathrm{kWh} / \mathrm{m}^{3}$ \\
\hline
\end{tabular}

Enerji tasarrufunun artmasiyla geri ödeme sürelerinin kısaldığ 1 bilinmektedir. En düşük geri ödeme süreleri soğuk iklime sahip DG4 bölgesinde hesaplanmıştır (Aydın and Bıyıkoğlu, 2019). Geri ödeme süreleri açısından karşılaştırma yapıldığında, geri ödeme süresindeki 6 aylık bir artışa karşılık yıllık yakıt tasarrufunda \%8 artış sağlandığı hesaplanmıştır. Dolayısıyla, soğuk iklim bölgelerinde optimum yalıtım kalınlığının artması sonucu yalıtım maliyeti yükselmekte ve geri ödeme süreleri kısalmaktadır. Bu bilgiler ışı̆̆ında çalışmada incelenen örnek bina DG4 bölgesinde olan Gümüşhane ilinde seçilmiştir. Derece / Gün bölgelerine göre 1s1 transfer katsayısı (U) değerleri Tablo 6'da verilmiştir.

Tablo 6. Derece / Gün bölgelerine göre tavsiye edilen maksimum U değerleri (URL-4)

\begin{tabular}{lllll}
\hline BÖLGE & $\mathrm{U}_{\text {duvar }}$ & $\mathrm{U}_{\text {tavan }}$ & $\mathrm{U}_{\text {taban }}$ & $\mathrm{U}_{\text {pencere }}$ \\
\hline DG1 & 0.7 & 0.45 & 0.7 & 2.4 \\
DG2 & 0.6 & 0.4 & 0.6 & 2.4 \\
DG3 & 0.5 & 0.3 & 0.45 & 2.4 \\
DG4 & 0.4 & 0.25 & 0.4 & 2.4 \\
\hline
\end{tabular}

\subsection{Hesap Yöntemi}

TS 825 standartlarında verilen toplam 1si transfer katsayıs1, yap1 elemanından iletim yoluyla gerçekleşen 1sı kaybı hesabı, doğal havalandırma yoluyla gerçekleşen $1 \mathrm{~s} 1$ kaybı hesabı ve y1llık

\section{Toplam Isı Transfer Katsayısı Hesaplama}

Bir odanın iletim ve taşınım ile 1sı kaybı;

$Q_{0}=\sum U A\left(T_{i c ̧}-T_{d l s ̧}\right)$

biçiminde hesaplanabilir. Burada; U: yapı bileşenlerinin toplam $1 \mathrm{~s} 1$ geçiş katsayısı $\left(\mathrm{W} / \mathrm{m}^{2} \mathrm{~K}\right)$, A: Yapı yüzeylerinin alanı $\left(\mathrm{m}^{2}\right), \mathrm{T}_{\text {iç }}$ ve $\mathrm{T}_{\text {dı̣s: }}$ İç ve dış ortam sıcaklıklarıdır $\left({ }^{\circ} \mathrm{C}\right)$.

a) Toplam 1 sı geçiş katsayısı (U)

$R_{\text {top }}^{\prime}=R_{\text {iç }}^{\prime}+\sum R_{\text {ilet }}^{\prime}+R_{d l s ̧}^{\prime}$

$U=\frac{1}{R_{\text {top }}^{\prime}}$ 
$Q=U A_{d}\left(T_{i c ̧}-T_{d l \grave{s}}\right)$

Yapı Elemanından İletim Yolu ile gerçekleşen Isı Kaybı Hesaplama

$H=H_{T}+H_{V}$

$H_{T}=\sum A U+I U_{I}$

$\sum A U=U_{D} A_{D}+U_{p} A_{p}+U_{k} A_{k}+0.8 U_{T} A_{T}+0.5 U_{t} A_{t}+U_{d} A_{d}+0.5 U_{d s} A_{d s}$

Doğal Havalandırma yoluyla gerçekleşen ısı kaybının hesaplanması

$H_{V}=\rho . c . V^{\prime}$

$H_{V}=\rho . c . V^{\prime}=\rho . c . n_{h} V_{h}=0.33 n_{h} V_{h}$

Yıllık Isıtma Enerjisi İhtiyacının Hesaplaması

$Q_{y l l}=\sum Q_{a y}$

$Q_{a y}=[\underbrace{H\left(\theta_{i}-\theta_{e}\right)}-\eta_{a y}(\underbrace{\phi_{i, a y}+\phi_{s, a y}})] \cdot t$

Is1 kayıplar1 Is1 kazançları

\section{Bulgular}

Yalıtım, binalarda enerji tasarrufu için en etkili yollardan biridir. $\mathrm{Bu}$ çalışmada TS 825 standartları kapsamında karşılaştırmalı olarak yalıtımsiz, k1smi yalıtımlı ve tam yalitıml durumlar için yıllık 1sıtma

enerjisi ihtiyaçları hesaplanmıştır. Bulgular, incelenen yalitım malzemeleri ve yalitım kalınlıklarına göre toplam isı transfer katsayısı, yıllık enerji ihtiyacı ve yüzde 1 sıl iyileşme grafikleri halinde sunulmuştur.
Şekil 10'dan da anlaşılacağ üzere hesaplamalarda kullanılan bütün yalıtım malzemeleri için yalıtım kalınlığının artışı ile dış hava ile temas halinde olan duvar için toplam 1S1 transfer katsayıs1 azalmıştır. 4. Derece gün bölgesinde bulunan bir il için tavsiye edilen maksimum 1 sı transfer katsayısı değeri (duvar için) $0.4 \mathrm{~W} / \mathrm{m}^{2} \mathrm{~K}$ olarak verilmiştir (Tablo 6). Hesaplamalar sonucunda tercih edilen her malzemenin ve malzeme kalınlığının bu kriteri sağladığ1 görülmüştür. Yalıtım kalınlığının artması ile $U$ değeri düşmüş, dolayısıyla daha iyi bir yalıtım sağlanmıştır.

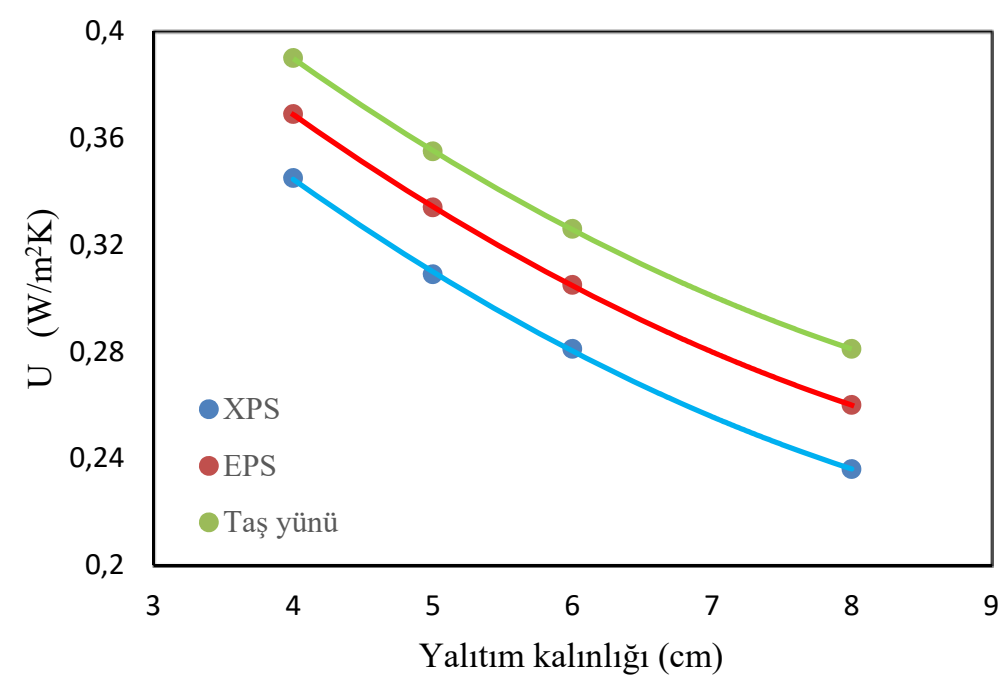

Şekil 10. Dış havaya açık duvarın farklı malzemeler ve kalınlıklar için U değerleri (W/m² K) 
Şekil 11'den de anlaşılacağı üzere yalıtım kalınlığının artışı ile yıllık enerji ihtiyacı azalmaktadır. Çalışmada incelenen malzemelerden aynı yalıtım kalınlığında en az y1llık enerji ihtiyacı XPS için tespit edilmiştir. Aşağıda verilen grafikte hesaplanan yalıtım malzemesi kalınlıkları her bir malzemenin ilgili kalınlıkta yaygın kullanımı ve piyasada bulunabilirliği de düşünülerek tercih edilmiştir. Örnek olarak seçilen mimari yapının duvar kesitinde kullanılan yapı elemanlarının değişmesi ile yıllık enerji ihtiyacının da değişeceği unutulmamalıdır. Yapılan bu örneklem dikkate alınarak aşağıda $\mathrm{MJ}$ cinsinden verilen yıllık enerji miktarı herhangi bir yakıt cinsinin 1 sıl değerine bölünerek yıllık yakıt miktarı hesaplanabilir ya da farklı kalınlıklardaki her bir malzemenin birim fiyatları üzerinden geri ödeme süreleri hesaplanabilir. Elde edilen bu veri seti benzer bir çalışma yapmak isteyen araştırmacılar için yol gösterici olacaktır.

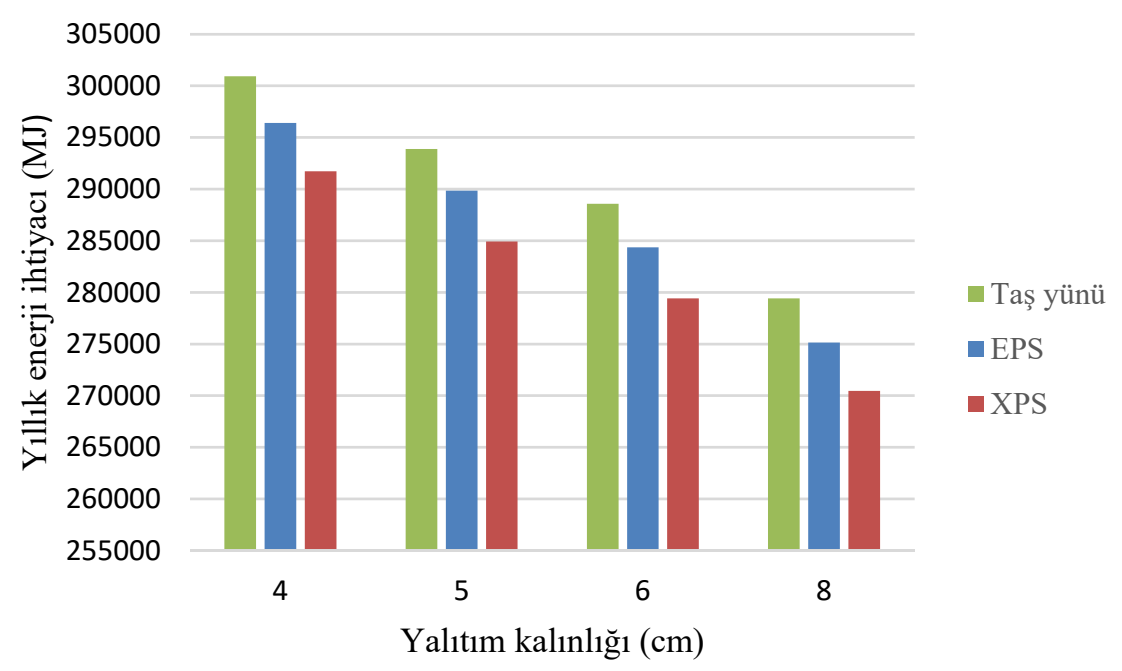

Şekil 11. Yalıtımlı durum için farklı yalıtım kalınlıkları ve farklı malzemelerin yıllık enerji ihtiyaçları

Şekil 12'de tam yalıtımlı ve yalıtımsız durumu karşılaştırmak için iyileşme grafiği verilmiştir. Burada tam yalitıml olarak kastedilen durum binanın taban, tavan, dış hava ile temaslı duvar ve toprak ile temaslı duvarlarının tamamının TS 825 standartlarına göre yalıtıldığ 1 durumu, yalıtımsız durum ise hiçbir yüzeyin yalıtılmadığ 1 durumu temsil etmektedir. Grafiğe göre aynı yalıtım kalınlığında yüzde iyileşme XPS için en yüksek değerdedir. Yalıtım kalınlığının artmasıyla yüzde iyileşme miktarı da artmıştır. Tam yalıtımlı ve yalıtımsız durumlarda farklı kriterler göz önünde bulundurularak sirasiyla \%38 ile $\% 44,5$ arasinda yüzde iyileşme sağlanmıştır.

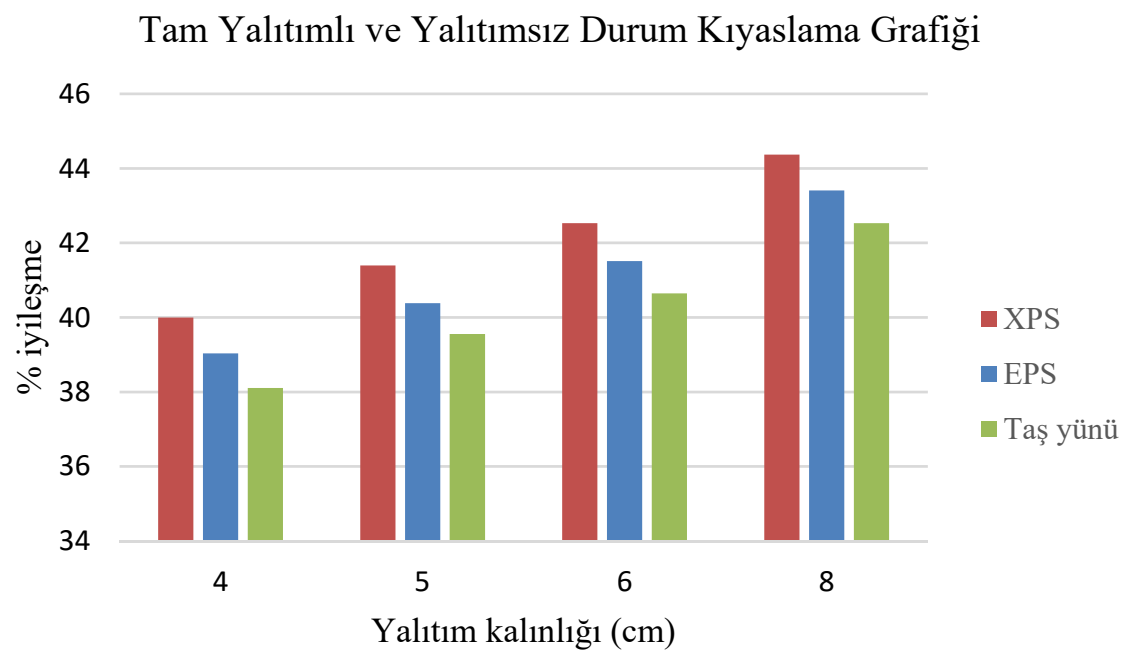

Şekil 12. Tam yalıtımlı durumun yalıtımsız durumla kıyaslanması 
Şekil 13'de tam yalıtımlı ve kısmi yalıtımlı durum (taban ve tavan yalıtımlı durum) için iyileşme grafiği verilmiştir. Burada tam yalıtımlı olarak kast edilen durum binanın taban, tavan, dış hava ile temaslı duvar ve toprak ile temaslı duvarlarının tamamının TS 825 standartlarına göre yalıtıldığ durumu, kismi yalitımlı durum ise taban ve toprağa temas eden duvarların yalıtımlı olduğu durumu temsil etmektedir. $\mathrm{Bu}$ iki durum kıyaslandığında farklı durumlar göz önünde bulundurularak \%13 ile \%23 arasında iyileşme sağlandığı anlaşılmaktadır.

Tam Yalıtımlı ve Kısmi Yalıtımlı Durum Kıyaslama Grafiği

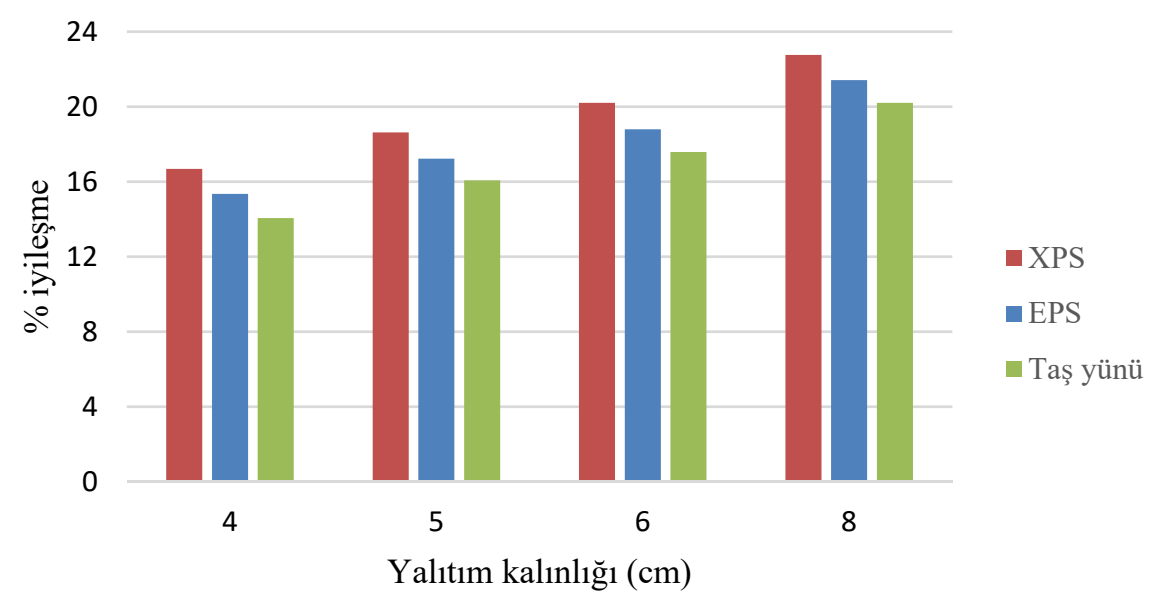

Şekil 13. Tam yalıtımlı durumun kısmi yalıtımlı durumla kıyaslanması

\section{Tartışma ve Sonuçlar}

Türkiye'nin enerji kaynaklarının sınırlı ve dışa bağımlı olmasından dolayı, özellikle enerji tüketiminin yoğun olduğu ve yüksek 1sı kaybına maruz kalan konut sektörü özelinde ve özellikle kaybın nispeten daha fazla olduğu 4. bölgede enerjinin verimli kullanımı her geçen gün daha fazla önem kazanmaktadır. Enerji kayb1 bütünleşik etkileriyle birlikte değerlendirildiğinde 1sı kaybına yönelik çözümlerden en önemlisi olan yalıtımla ilgili önerilerin, 2023 vizyonu enerji hedeflerini yakalamak için oldukça önemlidir. Bunun en etkili yolu 1sıtma yükünü azaltmaktır. $\mathrm{Bu}$ çalışmada, Gümüşhane iklim şartları ve meteorolojik değerleri göz önünde bulundurularak farklı yalıtım malzemeleri için yalıtım kalınlığının toplam 1S1 transfer katsayısina etkisi, farkl parametrelerin yalıtımsız ve kısmi yalıtıml duruma(tavan ve taban yalıtımlı) göre iyileşme yüzdeleri kıyaslamalı olarak değerlendirilmiştir. Yapilan hesaplamalar sonucunda elde edilen sonuçlar aşağıda sunulmuştur:

- Hesaplamalar 1s1, su, ses ve yangin yalıtımciları derneğinin (izoder) TS 825 standartları kapsamında oluşturdukları "İzoder TS 825 Hesap Programı" ile yapılmıştır. Mimarilerde kullanılan duvar elemanlarına göre uygulanması gereken yalıtım kalınlığının değişiklik gösterebileceğini belirterek, örnek mimarinin duvar kesit özellikleri dikkate alındığında Gümüşhane ili için uygulanması gereken minimum yalıtım kalınlığının $4 \mathrm{~cm}$ olduğu hesaplanmıştır.

- Çalışmada incelenen malzemelerden aynı yalıtım kalınlığında en az yıllık enerji ihtiyacı XPS için tespit edilmiştir. Bu değerler kısmi yalitıml durum (taban ve tavan yalitıml durum) için artan yalıtım kalınlığ 1 yönünde \%16-22 aralığında hesaplanmıştır. Tam yalıtımlı durumla kıyaslandığında bu değerler yine XPS için \%40-44 aralığında, EPS için \% 39-43.4 aralığında ve taş yünü için \% 38.142.5 aralığında elde edilmiştir. $\mathrm{Bu}$ değerler binada kullanılan yap1 malzemelerine, binanın cephesine ve pencere alanlarına göre değişiklik gösterebilir.

- Yapilan hesaplamalar sonucunda 1s1 yalitım malzemesi olarak kullanılan malzemenin cinsinin değişimi ile yıllık enerji ihtiyacının değiştiği, tamamen yalıtımsız duruma kıyasla çatının yalıtılması \%27.6 enerji tasarrufu, toprağa temas eden taban ve duvarların yalıtılması ile \%16.9 enerji tasarrufu sağlandığı hesaplanırken, dış ortama açık olan düşey duvarda ise kullanılan malzeme cinsine göre $\% 10.5-\% \quad 17$ arasinda enerji tasarrufu sağlanabileceği hesaplanmıştır. 
- Kullanılan yakıta, yalıtım malzemesine ve kalınlığına göre değişken olmasına rağmen, binalara uygulanan yalıtımların geri ödeme süreleri genellikle çok kısadır. Bu da ülkemizin enerji kaynakları konusundaki bağımlılığını azaltmaya katkıda bulunmaktadır. Bu durum hayati önem arz etmektedir.

- Grafiklerde verilen yıllık enerji ihtiyac1 verileriyle farklı tip 1sitma kaynakları ile (kömür, odun, doğalgaz, elektrik vs.) ne kadar yakıt tüketilmesi gerektiği ya da farklı yalıtım malzemelerinin birim fiyatları dikkate alınarak geri ödeme sürelerine ilişkin çalışmalar yapılabilir. Bu çalışmanın ilgi alanı içerisinde olmayan bu öneriler farklı çalışma gruplarının dikkatini çekebilir ve makalede sunulan veri seti kaynak olarak kullanılabilir.

\section{Kaynaklar}

Abd Alla, S., Bianco, V., Tagliafico, L.A. ve Scarpa, F., 2020. Life-Cycle Approach to The Estimation of Energy Efficiency Measures in The Buildings Sector. Applied Energy, 264, 114745 .

Altun, M. ve Akçamete, A., Application of TS 825 Turkish Thermal İnsulation Standard Using BIM, International Civil Engineering Architecture Conference, April 2019, Trabzon, Türkiye, 314-323.

Altun, M., Akgül, Ç.M. ve Akçamete, A., 2020. Kabuk Yalıtımının Bina Isitma Enerjisi İhtiyacına, Maliyetine ve Karbon Ayak İzine Etkisinin Yaşam Döngüsü Bakış Açısıyla Değerlendirmesi. Gazi Üniversitesi Mühendislik Mimarlık Fakültesi Dergisi, 35(1), 147-164 (in Turkish).

Aydın, N. ve Bıyıkoğlu, A., 2019. Türkiye'de Konut Tipi Binaların Isıtma Yükü Altında Ömür Maliyet Analizi Yöntemi ile Optimum Yalıtım Kalınlıklarının Belirlenmesi. Politeknik Dergisi, 22(4), 901-911 (in Turkish).

Bademlioğlu, A.H., Canbolat, A.S. ve Kaynaklı, Ö., 2018. Bina Dış Duvarlarında Yoğuşma Dikkate Alınarak Gerekli Yalıtım Kalınlığının Belirlenmesi: Bitlis İli İçin Örnek Çalışma. Uludağ University Journal of The Faculty of Engineering, 23(3), 333-340 (in Turkish).

Bolattürk, A., 2006. Determination of Optimum İnsulation Thickness For Building Walls with Respect to Various Fuels and Climate Zones in Turkey. Applied Thermal Engineering, 26(1112), 1301-1309.
Çomaklı, K. ve Yüksel B., 2003. Optimum İnsulation Thickness of External Walls For Energy Saving. Applied Thermal Engineering, 23(4), 473-479.

Derradji, L., Imessad, K., Amara, M. ve Errebai, F. B., 2017. A Study on Residential Energy Requirement and The Effect of The Glazing on The Optimum İnsulation Thickness. Applied Thermal Engineering, 112, 975-985.

Dikmen, N., 2019. 1995 Depremi Sonrası Dinar'da Kurulmuş Olan Afet Konutlarının TS 825 Binalarda Isı Yalıtım Kuralları'na Uygunluğu Açısından İncelenmesi. Uluslararası Teknolojik Bilimler Dergisi, 2(2), 50-59 (in Turkish).

Dylewski, R. ve Adamczyk, J., 2016. Study On Ecological Cost-Effectiveness For The Thermal İnsulation of Building External Vertical Walls in Poland. Journal of Cleaner Production, 133, 467-478.

Fertelli, A., 2013. Determination of Optimum İnsulation Thickness For Different Building Walls in Turkey. Transactions of FAMENA, 37(2), 103-113.

İmal, M. ve Karayiğit, S., 2014. Enerji Yönetmeliğine Göre Konutların Farklı Isı Yalıtım Malzemeleri ile Yalıtılmasının Ekonomik Analizi Üzerine Bir Araştırma: Kahramanmaraş Örneği. KSU Mühendislik Bilimleri Dergisi, 17(1), 1-9 (in Turkish).

Kotan, T., Fırat, İ., Kaya, M. ve Ulusu, İ., 2018. Binalarda Kullanılan Farklı Is1 Yalıtım Malzemelerinin Isı İletkenlik Katsayılarının Erzincan İli Şartlarında Termokupl ve Termal Kamera ile İncelenmesi. Uludağ University Journal of The Faculty of Engineering, 23(2), 367-382 (in Turkish).

Kurekci, N. A., 2016. Determination of Optimum İnsulation Thickness For Building Walls By Using Heating and Cooling Degree-Day Values of All Turkey's Provincial Centers. Energy and Buildings, 118, 197-213.

Meral, Ö., 2019. Soğuk İklim Bölgesinde Farklı Dış Duvar Yap1 Malzemelerinin Isıtma Yüküne Etkilerinin İncelenmesi. Frrat Üniversitesi Mühendislik Bilimleri Dergisi, 30(1), 105-113 (İn Turkish).

Rosti, B., Omidvar, A. ve Monghasemi, N., 2020. Optimal İnsulation Thickness of Common Classic and Modern Exterior Walls in Different Climate Zones of Iran. Journal of Building Engineering, 27, 100954.

Şahin, B. ve Çarkacı, C., 2019. Gümüşhane İli Kamu Binalarındaki Is1 Yalıtımı Uygulamalarının İncelenmesi. Gümüşhane Üniversitesi Fen 
Bilimleri Enstitüsü Dergisi, 9(3), 526-535 (in Turkish).

Uçar, A. ve Dumrul, M. U. ,2019. Bir Konutun Dış Duvarları İçin Isıtma ve Soğutma Yüklerine Göre Optimum Yalıtım Kalınlığın Tespiti ve Enerji Tasarrufu Analizi. Avrupa Bilim ve Teknoloji Dergisi, (16), 740-749 (in Turkish).

URL-1, www.Enerji.Gov.Tr/Tr-TR/Sayfalar/Elektrik. 6 Nisan 2020

URL-2, https://www.enerji.gov.tr. 7 Nisan 2020.

URL-3, http://www.imo.org.tr/resimler/ekutuphane/pdf/ 17182_44_51.pdf. 7 Nisan 2020.
URL-4, www.İzoder.Org.Tr/Sayfa/30/Ts-825-HesapProgrami. 8 Nisan 2020.

Uzun, İ., 2020. Isıtılan Mekanlarda İç ve Diş Ortam Sıcaklıklarına Bağlı Mevsimsel Yoğuşma Analizi. Uluslararası Mühendislik Araştırma ve Geliştirme Dergisi, 12(1), 292-299 (in Turkish).

Yaman, Ö., Şengül, Ö., Selçuk, H., Çalıkuş, O., Kara, İ., Erdem, Ş. ve Özgür, D., 2015. Binalarda Is1 Yalıtımı ve Isı Yalıtım Malzemeleri. Türkiye Mühendislik Haberleri (TMH) 487(4), 62-75 (in Turkish).

Yüksek, İ. ve Sıvacılar, S., 2017. Türkiye Şartlarında TS 825 Kapsamında Farklı Duvar Tiplerinin Isıl Etkinlikleri Üzerine Karşılaştırmalı Bir Çalışma. Politeknik Dergisi, 20(2), 291-302 (in Turkish). 